\title{
PENGARUH GOOD CORPORATE GOVERNANCE DAN TRANSAKSI HUBUNGAN ISTIMEWA TERHADAP EFFECTIVE TAX RATE (STUDI EMPIRIS PADA PERUSAHAAN MANUFAKTUR YANG TERDAFTAR DI BURSA EFEK INDONESIA TAHUN 2013-2017)
}

\author{
Ade Nilasari*), Irwan Setiawan \\ Universitas Pamulang \\ *)email: adenilasari13@gmail.com
}

Paper Accepted: 21 Juni 2019 Paper Reviewed: 23-29 Juni 2019 Paper Edited: 01-18 Juli 2019 Paper Approved: 30 Juli 2019

\begin{abstract}
ABSTRAK
Penelitian ini bertujuan untuk memperoleh bukti empiris tentang pengaruh good corporate governance dan transaksi hubungan istimewa terhadap effective tax rate. Good corporate governance yang diambil untuk pengujian ini adalah komisaris independen dan komite audit terhadap effective tax rate, dan transaksi hubungan istimewa yang digunakan adalah piutang hubungan istimewa. Jenis penelitian adalah kuantitatif asosiatif dan metodologi yang digunakan dalam penelitian ini adalah menggunakan analisis regresi berganda. Penelitian dilakukan pada 160 perusahaan manufaktur yang terdaftar di Bursa Efek Indonesia. Dengan menggunakan purposive sampling, yang dijadikan sampel penelitian adalah 70 perusahaan dengan pengamatan selama 5 (lima) tahun periode 20132017. Berdasarkan hasil pengujian, ditemukan bahwa H1 diterima, yaitu komisaris independen berpengaruh terhadap effective tax rate. Sedangkan $\mathrm{H} 2$ dan $\mathrm{H} 3$ ditolak, yaitu komite audit dan transaksi hubungan istimewa tidak berpengaruh terhadap effective tax rate. Namun secara simultan good corporate governance dan transaksi hubungan istimewa berpengaruh terhadap effective tax rate.
\end{abstract}

Kata Kunci : Good Corporate Governance, Transaksi Hubungan Istimewa, Effective Tax Rate.

\section{PENDAHULUAN}

Salah satu upaya atau kebijakan yang diterapkan perusahaan untuk meminimalkan jumlah pajak yang dibayar perusahaan, salah satunya adalah perusahaan dapat memilih metode akuntansi yang tepat untuk menurunkan effective tax rate (ETR). Dengan menggunakan tarif pajak efektif (effective tax rate/ETR) dapat dijadikan kategori pengukuran perencanaan pajak yang efektif.

Tarif pajak efektif perusahaan (Effective Tax Rate/ETR) sering digunakan sebagai salah satu acuan oleh para pembuat keputusan dan pihak-pihak yang berkepentingan untuk membuat kebijakan dalam perusahaan dan memuat kesimpulan sistem perpajakan pada perusahaan. Sesuai dengan Karayan dan Swenson (2007) dalam Ardyansah (2014), salah satu cara untuk mengukur seberapa baik sebuah perusahaan mengelola pajaknya adalah dengan melihat tarif efektifnya.

Dengan adanya beban pajak akan mengurangi laba bersih perusahaan. Oleh karena itu perusahaan akan berupaya semaksimal mungkin agar dapat membayar pajak sekecil mungkin. Fenomena perusahaan makanan dan minuman pertama terjadi beberapa tahun lalu Direktorat Jenderal Pajak telah menyelidiki kasus PT Coca Cola Indonesia. PT CCI diduga mengakali pajak sehingga menimbulkan kekurangan pembayaran pajak senilai Rp. 49,24 miliar. Sekarang kasus ini sedang dalam tahap banding di Pengadilan Pajak. PT CCI 
mengajukan banding karena merasa sudah membayar pajak sesuai ketentuan. Kasus ini terjadi untuk tahun pajak 2002, 2003, 2004 dan 2006. Hasil penelusuran Direktorat Jenderal Pajak (DJP), Kementerian Keuangan menemukan, ada pembengkakan biaya yang besar pada tahun itu. Beban biaya yang besar menyebabkan penghasilan kena pajak berkurang, sehingga setoran pajaknya pun mengecil. Beban biaya itu antara lain untuk iklan dengan rentang waktu tahun 2002-2006 dengan total sebesar Rp. 566,84 miliar. Itu untuk iklan produk minimum jadi merk Coca-Cola. Akibatnya, ada penurunan penghasilan kena pajak. Menurut DJP, total penghasilan kena pajak CCI pada periode itu adalah Rp. 603,48 miliar. Sedangkan perhitungan $\mathrm{CCI}$, penghasilan kena pajak hanyalah Rp. 492,59 miliar. Dengan selisih itu, DJP menghitung kekurangan pajak penghasilan $(\mathrm{PPh})$ CCI Rp. 49,24 miliar. Bagi DJP, beban biaya ini sangat mencurigakan dan mengarah pada praktik transfer pricing demi meminimalisir pajak. Transfer pricing merupakan transaksi barang dan jasa antara 15 beberapa divisi pada suatu kelompok usaha dengan harga yang tidak wajar, sehingga beban pajak berkurang. (10 Oktober 2017 | www.nasional.kontan.co.id).

Ada beberapa faktor yang dapat mempengaruhi perusahaan di dalam mempengaruhi effective tax rate di antaranya good corporate governance dengan proksi komisaris independen dan komite audit. Pencapaian laba perusahaan tidak luput dari pemilihan keputusan yang tepat dalam melakukan kegiatan perusahaan. Keputusan yang diambil perusahaan harus efektif, efisien dan tepat termasuk dalam penentuan kebijakan yang terkait tarif pajak efektif. Besaran tarif pajak efektif perusahaan bergantung pada beberapa aspek perusahaan seperti dalam pemilihan metode akuntansi maupun adanya pengaruh langsung dari pemegang saham. Ketika suatu perusahan telah menerapkan good corporate governance yang baik maka akan tercipta kinerja perusahaan yang efektif dan akan berdampak pada keputusan yang efektif dalam menentukan kebijakan yang terkait besaran tarif pajak efektif perusahaan.

Salah satu proksi dari good corporate governance adalah komisaris independen dan komite audit. Komisaris independen sebagai organ perusahaan bertugas dan bertanggung jawab secara kolektif untuk melakukan pengawasan dan memberikan nasihat kepada direksi serta memastikan bahwa perusahaan melaksanakan GCG (Hamdani, 2016:82). Komisaris independen juga memiliki peranan penting dalam perusahaan yaitu sebagai pengawas dan mengarahkan agar perusahaan beroperasi sesuai dengan peraturan yang berlaku. Komisaris independen menjadi penengah antara manajemen perusahaan dan pemilik perusahaan dalam pengambilan keputusan strategi atau kebijakan agar tidak melanggar peraturan yang berlaku, hal ini termasuk dalam keputusan perpajakan. Komisaris independen mempunyai peran yang cukup berpengaruh terhadap tingkat perusahaan dalam membayar pajak. Menurut Suyanto (2012) semakin banyak jumlah komisaris independen maka pengawasan terhadap agen akan semakin ketat. Karena adanya pengawasan lebih dari komisaris independen maka diprediksi tingkat pajak efektifnya sesuai dengan semestinya. Komisaris independen selalu mengawasi agar perusahaan mematuhi hukum dan peraturan yang berlaku.

Komite audit sesuai dengan Kep. 29/PM/2004 adalah komite yang dibentuk oleh dewan komisaris perusahaan yang anggotanya diangkat dan diberhentikan oleh dewan komisaris. Selain itu, komite audit merupakan komite tambahan yang bertujuan untuk melakukan pengawasan dalam proses penyusunan laporan keuangan perusahaan untuk menghindari kecurangan pihak manajemen. Komite audit juga berfungsi memberikan pandangan mengenai masalah yang berhubungan dengan kebijakan keuangan, akuntansi, dan pengendalian internal perusahaan (Diantari dan Ulupui, 2016).

Tanggung jawab komite audit dalam good corporate governance (GCG) adalah untuk memastikan bahwa perusahaan telah dijalankan sesuai dengan undang-undang yang berlaku, melaksanakan usahanya dengan beretika, melaksanakan pengawasannya secara efektif terhadap benturan kepentingan dan kecurangan yang dilakukan karyawan perusahaan. Semakin ketatnya pengawasan yang dilakukan pada suatu manajemen perusahaan maka akan menghasilkan suatu informasi yang berkualitas dan kinerja yang efektif (Hanum dan Zulaikha, 2013).

Transaksi hubungan istimewa merupakan transaksi yang rawan untuk terjadinya kerugian pada pihak-pihak terkait terutama bagi pemerintah. Transaksi hubungan istimewa pada dasarnya tidak dilarang. Transaksi hubungan istimewa sendiri merupakan transaksi antar perusahaan yang mempunyai hubungan tertentu. Adanya hubungan terikat antar perusahaan memungkinkan adanya rekayasa harga transaksi di luar harga wajar. Harga yang tidak wajar inilah yang menjadi sorotan dari pemerintah terutama dirjen pajak karena harga tersebut biasanya ditujukan untuk menghindari pajak. 
Harga yang tidak wajar sering dikenal dengan istilah transfer pricing (Desi dan Tobi, 2014:11).

Berkembangnya sistem perpajakan dan semakin ketatnya regulasi pemerintah mengenai sistem perpajakan yang ada di Indonesia, serta berdasarkan pada penelitian-penelitian terdahulu, maka penulis akan meneliti "Pengaruh Good Corporate Governance dan Transaksi Hubungan Istimewa Terhadap Effective Tax Rate" pada perusahaan manufaktur yang ada di Bursa Efek Indonesia. Penelitian ini hanya menggunakan perusahaan manufaktur dikarenakan karena perusahaan manufaktur cukup mendominasi perusahaan-perusahaan yang terdaftar di BEI, dan untuk mendapatkan hasil yang tidak bias dan akurat, karena setiap jenis bidang usaha memiliki peraturan dan kebijakan yang berbeda

\section{METODE PENELITIAN}

Penelitian ini menggunakan penelitian kuantitatif karena penelitian ini disajikan dengan menggunakan angka-angka. Menurut Sugiyono (2016) menyatakan metode kuantitatif dapat diartikan sebagai metode penelitian yang berlandaskan pada filsafat positivisme, digunakan untuk meneliti pada populasi dan sampel tertentu, pengumpulan data menggunakan instrument penelitian analisis data seperti kuantitatif/statistik dengan tujuan untuk menguji hipotesis yang diterapkan.

Data dalam penelitian ini adalah perusahaan manufaktur yang terdaftar di Bursa Efek Indonesia tahun 2013-2017. Sumber data yang digunakan adalah data sekunder yaitu sumber yang tidak langsung memberikan data kepada pengumpul data, misalnya lewat orang lain atau lewat dokumen (Sugiyono, 2016). Data sekunder dalam penelitian adalah data keuangan dan informasi yang terdapat dalam Annual Report perusahaan yang dijadikan sampel yang diolah menggunakan SPSS (Statistical Package for Sosial Sciences) versi 22.
Jadi penelitian yang dilakukan adalah observasi tidak langsung berupa data sekunder dengan menggunakan data yang ada pada situs www.idx.co.id. Untuk menganalisis permasalahan yang ada, penulis mendata laporan keuangan dari perusahaan manufaktur.

Variabel dalam penelitian ini terdapat dua kelompok utama yaitu variabel dependen dan variabel independen. Variabel dependen dalam penelitian ini adalah effective tax rate (ETR) sedangkan variabel independennya adalah Good Corporate Governance (X1) dan Transaksi Hubungan Istimewa (X2). Untuk lebih memperjelas lingkup dalam penelitian ini, tiaptiap variabel perlu didefinisikan agar lebih fokus dan tidak keluar dari permasalahan di luar definisi.

Variabel dependen dalam penelitian ini adalah Effective Tax Rate (Y). Effective tax rate semakin baik apabila nilai effective tax rate semakin rendah. Menurut Rodriguez dan Arias (2012) dalam (Ardyansah, 2014) effective tax rate dapat dihitung dari beban pajak dibagi dengan laba sebelum pajak dan tidak membedakan antara beban pajak kini dan beban pajak tangguhan sehingga dapat dirumuskan sebagai berikut:

$$
E T R=\frac{\text { Total Beban Pajak Penghasilan }}{\text { Laba Sebelum Pajak }} \times 100 \%
$$

Variabel independen dalam penelitian ini adalah Good Corporate Governance (X1) dan Transaksi Hubungan Istimewa (X2).

- Komisaris independen merupakan komisaris yang berasal dari luar perusahaan yang tidak mempunyai saham dalam perusahaan, dan tidak mempunyai hubungan baik langsung maupun tidak langsung berkaitan dengan kegiatan perusahaan. Variabel yang diukur dengan membagi jumlah komisaris independen dengan jumlah anggota dewan komisaris (Bakri, 2008) dalam (Ardyansah, 2014):

$$
\text { Proporsi Komisaris Independen }=\frac{\sum \text { Komisaris independen }}{\sum \text { Anggota Dewan Komisaris }} X 100 \%
$$

- Komite audit merupakan jumlah seluruh anggota komite audit dalam suatu perusahaan. Komite audit sesuai dengan aturan yang telah ditetapkan oleh BAPEPAM Kep-29/PM/2004 mewajibkan komite audit paling kurang terdiri dari 3 (tiga) orang anggota yang berasal dari komisaris independen dan pihak dari luar emiten atau perusahaan publik yang diketuai oleh komisaris independen. komite audit diukur dengan menghitung jumlah anggota komite audit dalam suatu perusahaan (Rahati Wulansari, 2014) sebagai berikut:

Komite Audit = Jumlah Komite Audit

- Pernyataan Standar Akuntansi Keuangan (PSAK) No. 7 (Revisi 2010), definisi dari pihak-pihak berelasi (dulunya disebut pihak- 
pihak yang mempunyai hubungan istimewa) adalah orang atau entitas yang terkait dengan entitas tertentu dalam menyiapkan laporan keuangannya. Pihak-pihak yang mempunyai hubungan istimewa dapat menyepakati transaksi dimana pihak-pihak yang tidak mempunyai hubungan istimewa tidak dapat melakukannya. Misalnya, entitas yang menjual barang kepada entitas induknya pada harga perolehan, mungkin tidak menjual dengan persyaratan tersebut kepada pelanggan lainnya. Selain itu, transaksi antara pihakpihak yang mempunyai hubungan istimewa mungkin tidak dilakukan dalam jumah yang sama, seperti dengan pihak-pihak yang tidak mempunyai hubungan istimewa (PSAK No.7 (Revisi 2010) paragraf 6). Menurut (Kartika Pertiwi, Tumpal Manik dan Asmaul Husna, 2017) Transaksi afiliasi menggunakan Rasio Piutang Hubungan Istimewa (RPHI) sebagai berikut:

$R P H I=\frac{\text { Piutang Hubungan Istimewa }}{\text { Total Asset Akhir Tahun }} \times 100 \%$

Variabel kontrol sering digunakan oleh peneliti, bila akan melakukan penelitian yang bersifat membandingkan. Variabel kontrol dalam penelitian ini adalah Leverage.

- Menurut Ardyansah (2014) Leverage merupakan banyaknya jumlah utang yang dimiliki perusahaan dalam melakukan pembiayaan dan dapat digunakan untuk mengukur besarnya aktiva yang dibiayai dengan utang. Leverage didefinisikan sebagai rasio dari hutang jangka panjang terhadap total aktiva. Leverage juga didefinisikan sebagai total hutang dibagi dengan total aktiva. Perusahaan yang menggunakan hutang akan menimbulkan adanya bunga yang harus dibayar. Pada peraturan perpajakan, yaitu pasal 6 ayat 1 UU nomor 36 tahun 2008 tentang $\mathrm{PPh}$, bunga pinjaman merupakan biaya yang dapat dikurangkan (deductible expense) terhadap penghasilan kena pajak. Beban bunga yang bersifat deductible akan menyebabkan laba kena pajak perusahaan menjadi berkurang. Laba kena pajak yang berkurang pada akhirnya akan mengurangi jumlah pajak yang harus dibayar perusahaan (Rachmithasari, 2015). Variabel ini diukur dengan membagi seluruh total kewajiban dengan ekuitas dimana semakin tinggi rasio ini berarti modal sendiri (pribadi) semakin sedikit dibanding dengan utang yang harus dibayar. Besaran utang perusahaan tidak boleh melebihi modal sendiri agar beban tetap tidak terlalu tinggi sehingga tidak memberatkan. Semakin kecil rasio ini maka semakin baik karena porsi utang terhadap modal semakin kecil sehingga kondisi keuangan perusahaan semakin aman. Menurut (Weston dan Copeland, 1997) dalam (Ardyansah, 2014) Variabel ini diukur dengan membagi seluruh total kewajiban dengan ekuitas yang dirumuskan sebagai berikut:

Leverage $=\frac{\text { Total Kewajiban }}{\text { Ekuitas }} \times 100 \%$

Populasi pada penelitian ini adalah perusahaan manufaktur yang terdaftar di Bursa Efek Indonesia (BEI) pada periode tahun 2013 hingga 2017, dipilih periode 2013 hingga 2017 dikarenakan untuk meneliti perusahaan manufaktur dengan tahun terbaru.

Sedangkan model sampel yang digunakan pada penelitian ini adalah purposive sampling yang merupakan teknik pengambilan sampel non random sampling. Non random sampling mempunyai arti bahwa pengambilan sampel yang tidak semua anggota populasi mendapat kesempatan untuk dipilih menjadi sampel. Metode purposive sampling harus menentukan kriteria yang ditentukan untuk mendapatkan sampel yang representative. Kriteria yang ditetapkan dalam pengambilan sampel pada penelitian ini ditentukan sebagai berikut:

1. Perusahaan manufaktur yang secara berturutturut menyediakan laporan tahunan di Bursa Efek Indonesia tahun 2013 - 2017;

2. Perusahaan manufaktur tersebut tidak delisting selama periode pengamatan;

3. Perusahaan Manufaktur yang mempublikasikan laporan keuangannya secara lengkap dan konsisten selama tahun penelitian 2013-2017;

4. Perusahaan Manufaktur yang laporan keuangannya menggunakan mata uang rupiah tahun 2013-2017;

5. Tidak memiliki laba yang negatif/rugi. Perusahaan yang mengalami rugi berarti tidak menanggung beban pajak. Apabila ada beban pajak, merupakan beban pajak tahun berjalan;

6. Perusahaan Manufaktur yang menyajikan laporan keuangan serta memiliki informasi yang lengkap terkait dengan variabel yang diteliti tahun 2013-2017.

Sumber data yang digunakan adalah data sekunder yaitu sumber yang tidak langsung memberikan data kepada pengumpul data, misalnya lewat orang lain atau lewat dokumen. Data sekunder dalam penelitian adalah data keuangan dan informasi yang terdapat dalam 
Annual Report perusahaan yang dijadikan sampel.

Teknik pengumpulan data dalam penelitian ini adalah dengan teknik observasi non partisipan, yaitu mengumpulkan data dari dokumen-dokumen yang sudah ada dan mencatat data, serta informasi yang diperlukan dalam penelitian. Setelah memperoleh daftar semua perusahaan non-keuangan selama periode tahun 2013-2017 dari IDX Fact Book tahun 2013-2017, kemudian mengakses laporan tahunan dan laporan keuangan tahunannya mengumpulkan data-data yang dibutuhkan.

Metode analisis yang digunakan dalam penelitian ini adalah uji statistik deskriptif dan teknik analisis regresi berganda dan diolah menggunakan SPSS (Statistical Package for Sosial Sciences) versi 22. Metode analisis yang digunakan untuk memperkirakan secara kuantitatif pengaruh dari beberapa variabel independen secara bersama-sama maupun secara sendiri-sendiri terhadap variabel dependen. metode analisis data yang digunakan untuk penelitian ini adalah dengan menggunakan uji statistik berupa :

- Uji Deskriptif. Menurut Ghozali (2018) uji statistik deskriptif adalah statistik yang memberikan gambaran atau deskripsi suatu data yang dilihat dari nilai rata-rata (mean), standar deviasi, varian, maksimum, minimum, sum, range. Untuk memberikan gambaran analisis statistik deskriptif. Dalam statistik deskriptif juga dapat dilakukan mencari kuatnya hubungan antar variabel melalui analisis korelasi, melakukan prediksi dengan analisis regresi dan membuat perbandingan dengan membandingkan rata-rata sampel atau populasi.

- Pengujian asumsi klasik normalitas adalah pengujian tentang kenormalan distribusi data. Uji normalitas bertujuan untuk menguji apakah dalam model regresi, variabel pengganggu atau residual memiliki distribusi normal. Model regresi yang baik adalah distribusi datanya normal atau mendekati normal. Uji $\mathrm{t}$ dan $\mathrm{F}$ mengasumsikan bahwa nilai residual mengikuti distribusi normal. Ada dua cara untuk mendeteksi apakah residual berdistribusi normal atau tidak yaitu dengan analisis grafik dan uji statistik (Ghozali, 2018). Untuk mendeteksi normalitas dapat digunakan grafik normal P-Plot. Data tersebut normal atau tidak dapat diuraikan sebagai berikut :

1. Jika data menyebar diatas garis diagonal dan mengikuti arah garis diagonal atau grafik histogramnya menunjukkan pola distribusi normal, maka model regresi memenuhi asumsi normalitas.
2. Jika data menyebar jauh dari garis diagonal dan tidak mengikuti arah garis diagonal atau grafik histogramnya tidak menunjukkan pola distribusi normal, maka model regresi tidak memenuhi asumsi normalitas.

- Pengujian normalitas dengan grafik dapat menyesatkan apabila tidak berhati-hati, secara visual seperti terlihat normal padahal secara statistik bisa sebaliknya. Oleh sebab itu dianjurkan disamping uji grafik dilengkapi dengan uji statistik. Uji lain yang dapat digunakan untuk menguji normalitas adalah uji statistik non-parametrik Kolmogorov-Smirnov (K-S). Uji K-S dilakukan dengan melihat angka probablitasnya dengan ketentuan (Ghozali, 2018):

1. Nilai signifikansi atau nilai probabilitas < 0,05 maka distribusi dikatakan tidak normal.

2. Nilai signifikansi atau nilai probabilitasnya > 0,05 maka distribusi dikatakan normal.

- Pengujian asumsi klasik heteroskedastisitas bertujuan untuk menguji apakah dalam model regresi terjadi ketidaksamaan variance dari residual satu pengamatan ke pengamatan yang lain. Jika variance dari residual suatu pengamatan ke pengamatan lain tetap, maka disebut Homokedastisitas dan jika berbeda disebut Heterokedastisitas. Model regresi yang baik adalah yang Homokedastisitas atau tidak terjadi Heteroskedastisitas (Ghozali, 2018). Dalam penelitian ini, untuk mendeteksi ada atau tidaknya heteroskedastisitas didalam model regresi dilakukan dengan melihat grafik scatterplot. Metode tersebut dilakukan dengan cara melihat grafik Scatterplot antara ZPRED atau variabel dependen dengan SRESID atau residualnya (Ghozali, 2018:138). Dasar analisis untuk melihat hasil uji heteroskedsatisitas yaitu sebagai berikut:

1. Jika ada pola tertentu, seperti titik-titik yang ada membentuk pola tertentu yang teratur (bergelombang, melebar kemudian menyempit), maka mengindikasikan telah terjadi heteroskedstisitas.

2. Jika tidak ada pola yang jelas, serta titiktitik menyebar diatas dan dibawah angka 0 pada sumbu y, maka tidak terjadi heteroskedstisitas.

- Pengujian asumsi klasik multikolonieritas bertujuan untuk menguji apakah model regresi ditemukan adanya korelasi antar variabel bebas (independen). Model regresi yang baik seharusnya tidak terjadi korelasi diantara variabel independen. Jika variabel independen saling berkorelasi, maka variabel-variabel ini 
tidak ortogonal. Variabel ortogonal adalah variabel independen yang nilai korelasi antar sesama variabel independen sama dengan nol (Ghozali, 2018:107). Untuk mendeteksi ada atau tidaknya multikolinieritas didalam model regresi dalah sebagai berikut jika nilai tolerance dan lawannya serta dari Variance Inflation Factor (VIF). Kedua ukuran ini menunjukkan setiap variabel independen manakah yang dijelaskan oleh variabel independen lainnya. Dalam pengertian sederhana setiap variabel independen menjadi variabel dependen (terikat) dan di regres terhadap variabel independen lainnya (Ghozali, 2018). Jadi nilai tolerance yang rendah sama dengan nilai VIF yang tinggi (karena VIF $=1 /$ Tolerance). Nilai cutoff yang umum dipakai unruk menunjukkan adanya kolinieritas yang masih dapat ditolerir. Jadi kriteria pengujian untuk lulus dari uji multikolinieritas adalah :

1. Nilai tolerance $>0,10$

2. Nilai Variance Inflation Factor (VIF) $<10$

- Pengujian asumsi klasik autokorelasi bertujuan untuk mengetahui ada tidaknya korelasi antara variabel pengganggu pada periode tertentu dengan variabel pengganggu periode sebelumnya. Autokorelasi muncul karena observasi yang berurutan sepanjang waktu berkaitan satu sama lainnya. Masalah ini timbul karena residual tidak bebas dari suatu observasi ke observasi lainnya. Uji autokorelasi dapat dilakukan dengan menggunakan Uji Durbin-Watson (DW test). Menurut Ghozali (2018:112) uji DurbinWatson hanya digunakan untuk autokorelasi tingkat satu dan mensyaratkan adanya intercept (konstanta) dalam model regresi dan tidak ada variabel lag di antara variabel independen. Hipotesis yang akan diuji adalah :

H0 : tidak ada autokorelasi $(r=0)$

Ha : ada auto korelasi $(r \neq 0)$

- Analisis regresi berganda digunakan untuk menguji pengaruh dua variabel atau lebih variabel independen terhadap variabel dependen apakah masing-masing variabel independen berhubungan positif atau negatif dan untuk memprediksi nilai dari variabel dependen apabila nilai variabel independen mengalami kenaikan atau penurunan (Ghozali, 2018). Menurut Ghozali (2018) ketepatan fungsi regresi sampel dalam menaksir nilai aktual dapat diukur dari Goodness of fit nya. Secara statistik setidaknya ini dapat diukur dari nilai koefisien determinasi, nilai statistik F dan nilai statistik t. Perhitungan statistik disebut signifikan secara statistik apabila nilai uji statistiknya berada di dalam daerah kritis (daerah dimana H0 ditolak). Sebaliknya disebut tidak signifikan bila nilai uji statistik nya berada dalam daerah dimana $\mathrm{H} 0$ diterima.Variabel dependen yang digunakan dalam penelitian ini adalah Effective Tax Rate. Sedangkan untuk variabel independen yang digunakan dalam penelitian ini yaitu Good Corporate Governance dengan proksi dari Komisaris Independen (X1), Komite Audit (X2), Transaksi Hubungan Istimewa (X3) dan Leverage (X4) sebagai variabel kontrol. Model regresi dalam penelitian ini dapat dirumuskan sebagai berikut:

$\mathrm{Y}=\alpha+\beta 1 \mathrm{X} 1+\beta 2 \mathrm{X} 2+\beta 3 \mathrm{X} 3+\beta 4 \mathrm{X} 4+\mathrm{e}$

Keterangan :

$\mathrm{Y} \quad=$ Effective Tax Rate

$\alpha=$ Konstanta

$\mathrm{X} 1=$ Komisaris Independen

$\mathrm{X} 2=$ Komite Audit

$\mathrm{X} 3=$ Transaksi Hubungan Istimewa

$\mathrm{X} 4=$ Leverage

e $\quad=$ Variabel diluar model (error)

- Pengujian hipotesis yang dilakukan dalam penelitian ini berkaitan dengan ada tidaknya pengaruh variabel bebas terhadap variabel terikat yang menggunakan rancangan hipotesis melalui penetapan hipotesis nol (H0) tidak terdapat pengaruh yang signifikan, hipotesis alternatif (Ha) adanya pengaruh antara variabel bebas dan variabel terikat, penelitian uji statistik dan perhitungan nilai uji statistik, perhitungan hipotesis, penetapan tingkat signifikan, dan penarikan kesimpulan (Rifkhan, 2017). Adapun terdapat 3 (tiga) hipotesis yang dilakukan, yaitu :

1. Siginifikansi Parameter Individual (Uji-t) t-test digunakan untuk mengetahui apakah variabel bebas signifikan atau tidak terhadap variabel terikat secara individual untuk setiap variabel (Sugiyono, 2013). Menurut Ghozali (2016) nilai thitung hasil perhitungan dalam penelitian ini selanjutnya dibandingkan dengan nilai ttabel dengan menggunakan tingkat kesalahan 0,05 dengan kriteria yang digunakan adalah $\mathrm{Ha}=$ diterima jika nilai -ttabel < thitung < ttabel dengan nilai nilai probabilitas 0,05 lebih besar atau sama dengan nilai probabilitas Sig atau (0,05>Sig), maka Ho ditolak dan $\mathrm{Ha}$ diterima artinya signifikan, sedangkan Ho 
$=$ diterima jika nilai thitung $>$ ttabel atau thitung < -ttabel dengan nilai probabilitas 0,05 lebih kecil atau sama dengan nilai probabilitas Sig atau $(0,05<\mathrm{Sig})$, maka Ho diterima dan $\mathrm{Ha}$ ditolak artinya tidak signifikan.

2. Signifikansi Simultan (Uji-F) adalah pengujian terhadap koefisien regresi secara simultan. Pengujian ini dilakukan untuk mengetahui pengaruh semua variabel independen yang terdapat di dalam model secara bersama-sama (simultan) terhadap variabel dependen yaitu faktor-faktor yang mempengaruhi kinerja dosen universitas pamulang secara bersama-sama (Sugiyono, 2013). Menurut Ghozali (2016) nilai Fhitung hasil perhitungan dalam penelitian ini selanjutnya dibandingkan dengan nilai Ftabel yang diperoleh dengan menggunakan tingkat resiko atau signifikan level 5\% atau dengan degree freedom $=\mathrm{n}-\mathrm{k}-1$ dengan kriteria yang digunakan adalah diterima jika nilai Ftabel < Fhitung < Ftabel dengan nilai nilai probabilitas 0,05 lebih besar atau sama dengan nilai probabilitas Sig atau (0,05>Sig) maka Ho ditolak dan $\mathrm{Ha}$ diterima artinya signifikan, sedangkan jika nilai Fhitung > Ftabel atau Fhitung < Ftabel dengan nilai probabilitas 0,05 lebih kecil atau sama dengan nilai probabilitas Sig atau $(0,05<$ Sig $)$ maka Ho diterima dan Ha ditolak artinya tidak signifikan.

3. Koefisien Determinasi (KD) adalah Untuk mengukur seberapa besar variabel-variabel bebas dapat menjelaskan variabel terikat dengan nilai $\mathrm{KD}$ berada pada interval $0<\mathrm{r} 2<1$, secara logika dapat diketahui bahwa makin baik estimasi model dalam menggambarkan data maka makin dekat nilai r2 ke nilai 1 (satu) (Sugiyono, 2013). Sedangkan Menurut Ghozali (2016) nilai selanjutnya untuk mengetahui signifikansi bandingkan antara nilai probabilitas 0,05 dengan nilai probabilitas Sig. F Change apabila nilai probabilitas 0,05 lebih besar atau sama dengan nilai probabilitas Sig. F Change atau (0,05 > Sig. F Change) maka Ho ditolak dan $\mathrm{Ha}$ diterima artinya signifikan, sedangkan nilai probabilitas 0,05 lebih kecil atau sama dengan nilai probabilitas Sig. F Change atau $(0,05<$ Sig. F Change), maka Ho diterima dan $\mathrm{Ha}$ ditolak artinya tidak signifikan.

\section{HASIL DAN PEMBAHASAN}

Penelitian ini dilakukan terhadap perusahaan manufaktur yang terdaftar di Bursa Efek Indonesia. Periode pengamatan yang digunakan dalam penelitian ini adalah tahun 2013-2017. Fokus pada penelitian ini adalah ingin melihat pengaruh good corporate governance dan transaksi hubungan istimewa terhadap effective tax rate pada perusahaan manufaktur.

Perusahaan manufaktur (manufacturing) merupakan salah satu dari tiga macam perusahaan selain perusahaan dagang (merchandising) dan perusahaan jasa (service) ditinjau dari jenis usaha dan cara mendapatkan laba. Perusahaan manufaktur adalah perusahaan atau badan usahan yang melakukan aktivitas pengolahan bahan mentah ataupun bahan setengah jadi. Dari sekian banyak perusahaan, perusahaan manufaktur yang terdaftar di BEI dibagi dalam tiga sektor. Sektor tersebut adalah industri dasar dan kimia, aneka industri dan industri barang konsumsi.

Adapun ketiga sektor bagian tersebut terdiri dari beberapa jenis sebagai berikut :

1. Industri dasar dan kimia : Semen, keramik, kaca dan porselin, metal dan sejenisnya, kimia, plastik dan kemasan, pakan ternak, kertas dan alat tulis, dan lain-lain.

2. Aneka industri : Mesin dan alat berat, Otomotif dan komponennya, tekstil dan garment, alas kaki, kabel, elektronik, dan lain-lain.

3. Industri barang konsumsi : Makanan dan minuman, pabrik rokok, farmasi, kosmetik dan barang keperluan rumah tangga.

Dalam penelitian ini, total perusahaan manufaktur yang terdaftar di Bursa Efek Indonesia (BEI) selama tahun 2013-2017 adalah sebanyak 160 perusahaan. Berdasarkan populasi perusahaan manufaktur yang terdaftar di Bursa Efek Indonesia (BEI) periode tahun 2013-2017, penelitian ini menggunakan beberapa sampel, yaitu penentuan sampel berdasarkan kriteria tertentu. Adapun data yang digunakan adalah data sekunder yang berasal dari laporan keuangan tahun 2013-2017 yang dapat diunduh melalui situs resmi Bursa Efek Indonesia (BEI) pada alamat website www.idx.co.id.

Sedangkan untuk jumlah sampel yang digunakan dalam penelitian ini yaitu dari 160 perusahaan yang terdaftar, terdapat perusahaan manufaktur yang tidak delisting selama periode penelitian tahun 2013-2017 berjumlah 152, perusahaan Manufaktur yang mempublikasikan laporan keuangannya secara lengkap dan konsisten selama tahun penelitian berjumlah 
128, perusahaan manufaktur yang laporan keuangannya menggunakan mata uang rupiah berjumlah 108, perusahaan manufaktur yang tidak mengalami kerugian selama periode tahun penelitian 2013-2017 berjumlah 69, perusahaan manufaktur yang menyajikan laporan keuangan serta memiliki informasi yang lengkap terkait dengan variabel yang diteliti tahun 2013-2017 berjumlah 33 perusahaan.

Berdasarkan data 33 perusahaan diatas, peneliti melakukan uji normalitas terlebih dahulu yang berfungsi untuk mengetahui apakah data sampel berasal dari populasi yang berdistribusi normal atau tidak. Berikut ini hasil uji normalitas:

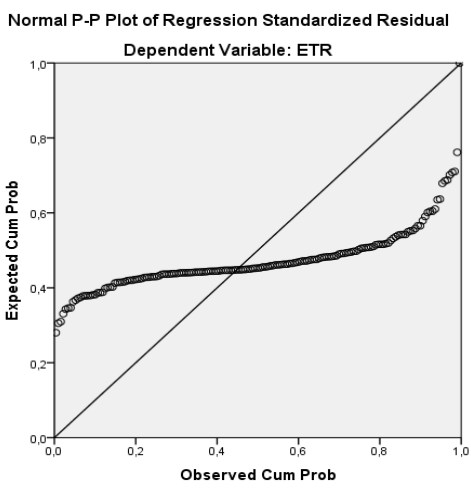

\section{Gambar 1. Uji Normalitas dengan P-Plot}

Berdasarkan gambar 1 terlihat bahwa titiktitik plot tidak konsisten mendekati garis diagonal dan sebagian titik terlihat menjauhi garis diagonal yang menandakan data tidak normal. Salah satu cara mengatasi data berdistribusi tidak normal adalah dengan mengurangi jumlah data, yaitu data-data yang dinilai ekstrim (data outlier). Data outlier yaitu data yang muncul dengan nilai ekstrim, yang dimaksud dengan nilai ekstrim adalah nilai yang jauh berbeda dengan sebagian nilai lain yang terdapat dalam kelompok tersebut. Penyebab adanya data outlier biasanya karena kesalahan dalam melakukan entri data dan variabel dalam populasi tersebut memiliki nilai ekstrim atau berdistribusi tidak normal.

Dari hasil seleksi berdasarkan pengurangan jumlah data, didapatkanlah sebanyak 14 perusahaan yang telah diseleksi dari total 33 perusahaan yang datanya tidak berdistribusi normal dalam kurun waktu dari tahun 20132017, maka didapatkanlah data sebanyak 70 data yang digunakan dalam penelitian ini.

Hasil dari pengujian statistic deskriptif untuk penelitian ini sebagai berikut:

Descriptive Statistics

\begin{tabular}{|l|r|r|r|r|r|}
\hline & \multicolumn{1}{|c|}{$\mathrm{N}$} & \multicolumn{1}{|c|}{ Minimum } & \multicolumn{1}{c|}{ Maximum } & \multicolumn{1}{c|}{ Mean } & \multicolumn{1}{c|}{ Std. Deviation } \\
\hline Komisaris independen & 70 &, 17 & 1,00 &, 4416 &, 19303 \\
Komite audit hubungan & 70 & 3,00 & 4,00 & 3,1143 &, 32046 \\
Transaksi & 70 &, 00 &, 33 &, 0764 &, 10784 \\
istimewa & 70 &, 08 & 2,65 &, 8310 &, 62470 \\
Leverage & 70 &, 17 &, 33 &, 2497 &, 02514 \\
Effective Tax Rate & 70 & & & \\
Valid N (listwise) & & & \\
\hline
\end{tabular}

Sumber : Output SPSS 22

Berdasarkan hasil tabel 1 maka dapat dijelaskan sebagai berikut :

1. Banyak jumlah sampel penelitian (N) adalah 70. Jumlah tersebut merupakan perusahaan manufaktur selama 5 tahun pengamatan pada penelitian dari tahun 2013-2017, dimana setiap tahunnya 14 perusahaan.

2. Komisaris Independen yang diukur melalui jumlah komisaris independen dibagi jumlah anggota dewan komisaris memiliki nilai minimum sebesar 0,17 dan nilai maksimum sebesar 1,00. Nilai rata-rata (mean) dari komisaris independen yaitu sebesar 0,4416 dengan standar deviasi sebesar 0,19303.

3. Komite audit yang diukur melalui komite audit $=$ jumlah komite audit memiliki nilai minimum sebesar 3,00 dan nilai maksimum sebesar 4,00. Nilai rata-rata (mean) dari komite audit yaitu sebesar 3,1143 dengan standar deviasi sebesar 0,32046.

4. Transaksi hubungan istimewa yang diukur melalui piutang hubungan istimewa dibagi total aset akhir tahun memiliki nilai minimum sebesar 0,00 dan nilai maksimum sebesar 0,33. Nilai rata-rata (mean) dari transaksi hubungan istimewa yaitu sebesar 0,0764 dengan standar deviasi sebesar 0,10784 .

5. Leverage sebagai variabel kontrol yang diukur melalui total kewajiban dibagi ekuitas memiliki nilai minimum sebesar 0,08 dan niai maksimum sebesar 2,65. Nilai rata-rata (mean) dari leverage sebagai variabel kontrol sebesar 0,8310 dengan standar deviasi 0,62470 .

6. Effective tax rate yang diukur melalui total beban pajak penghasilan dibagi laba sebelum 
pajak memiliki nilai minimum sebesar 0,17 dan nilai maksimal sebesar 0,33 . Nilai ratarata (mean) dari effective tax rate sebesar 0,2497 dengan standar deviasi 0,02514.

Kemudian untuk hasil pengujian normalitas data setelah dilakukan outlier maka didapatkan hasil sebagai berikut:

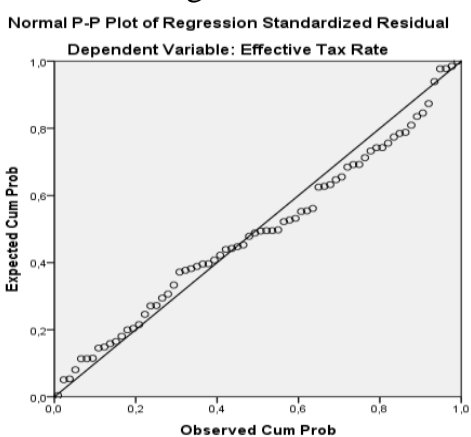

Gambar 2. Uji Normalitas dengan P-Plot Setelah Outlier

Berdasarkan gambar 2 P-Plot diatas dapat dilihat bahwa setelah dilakukan metode dengan membuang data outlier maka titik-titik plot mendekati garis diagonal sehingga dapat disimpulkan bahwa data-data dalam penelitian ini adalah normal dan memenuhi syarat dalam asumsi normalitas. Selain itu untuk hasil normalitas berdasarkan gambar histogram didapatkan hasil sebagai berikut:

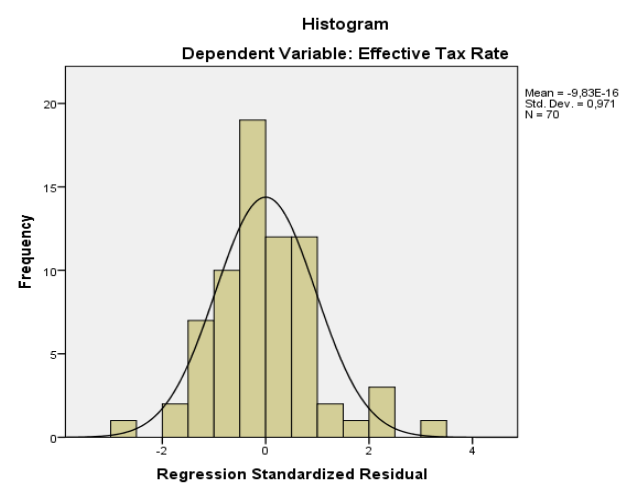

Gambar 3. Uji Normalitas dengan Histogram

Pada gambar histogram diatas dapat dilihat bahwa grafik membentuk seperti gunung atau lonceng, sehingga dapat dikatakan data terdistribusi normal.

Kemudian untuk hasil uji normalitas dengan menggunakan hasil uji KolmogorovSmirnov didapatkan hasil sebagai berikut:
Tabel 2. One Sample Kolmogorov Smirnov Test

\begin{tabular}{|ll|r|}
\hline & & \multicolumn{2}{|c|}{$\begin{array}{c}\text { Unstandardized } \\
\text { Residual }\end{array}$} \\
\hline $\mathrm{N}$ & & 70 \\
Normal & Mean &, 0000000 \\
Parameters ${ }^{\mathrm{a} b}$ & Std. &, 02274057 \\
& Deviation &, 080 \\
Most Extreme & Absolute &, 080 \\
Differences & Positive &,- 068 \\
& Negative &, 080 \\
Test Statistic & &, $200^{\mathrm{c}, \mathrm{d}}$ \\
Asymp. Sig. (2-tailed)
\end{tabular}

a. Test distribution is Normal.

b. Calculated from data.

c. Lilliefors Significance Correction.

Berdasarkan tabel 2 dapat dilihat nilai Asymp. Sig. (2-tailed) sebesar 0,200 atau 0,200 yang berarti $0,200<0,05$. Sehingga dapat dibuktikan bahwa data yang digunakan dalam penelitian ini normal.

Pada hasil pengujian heteroskedastisitas digunakan uji koefisien korelasi grafik scatterplot, maka hasilnya sebagai berikut:

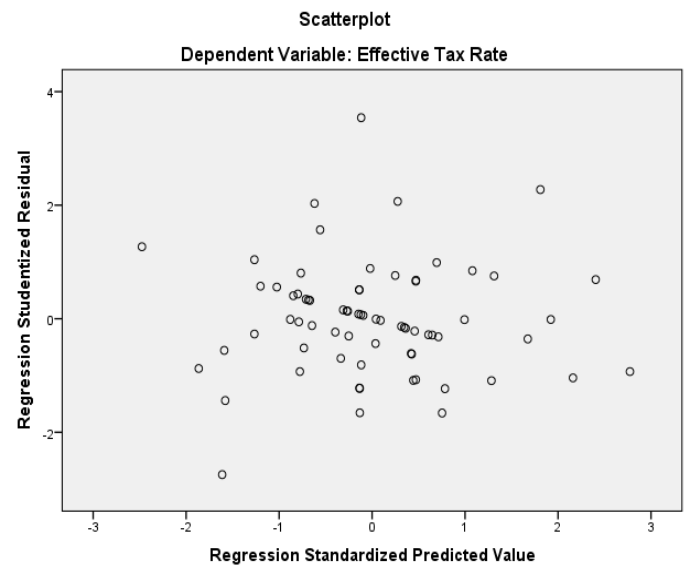

\section{Gambar 4. Uji Heteroskedastisitas dengan Scatterplot}

Hasil dari gambar 4 dapat diketahui bahwa titik-titik tidak membentuk pola yang jelas, dan titik-titik menyebar diatas dan dibawah angka 0 pada sumbu Y. Jadi dapat disimpulkan bahwa tidak terjadi heteroskedastisitas dalam model regresi.

Pada hasil uji multikolinieritas didapatkan hasil sebagai berikut: 
Tabel 3. Hasil Uji Multikolonieritas

\begin{tabular}{|c|c|c|}
\hline \multicolumn{3}{|c|}{ Coefficients $^{\mathrm{a}}$} \\
\hline \multirow[b]{2}{*}{ Model } & \multicolumn{2}{|c|}{ Collinearity Statistics } \\
\hline & Tolerance & VIF \\
\hline $1 \quad$ (Constant) & & \\
\hline Komisaris independen & ,974 & 1,027 \\
\hline Komite audit & ,902 & 1,109 \\
\hline $\begin{array}{l}\text { Transaksi hubungan } \\
\text { istimewa }\end{array}$ & ,901 & 1,110 \\
\hline Leverage & ,972 & 1,029 \\
\hline
\end{tabular}

a. Dependent Variable: Effective Tax Rate

Berdasarkan hasil dari tabel 3 maka dapat dilihat bahwa nilai tolerance komisaris independen 0,974 , komite audit 0,902, transaksi hubungan Istimewa 0,901 dan leverage sebagai variabel kontrol 0,972. Pada kolom VIF, hasil yang diperoleh komisaris independen 1,027, komite audit 1,109, transaksi hubungan istimewa 1,110 dan leverage sebagai variabel kontrol 1,029. Angka-angka tersebut menunjukan bahwa tolerance lebih besar dari 0,1 dan VIF lebih kecil dari 10. Dengan demikian dapat disimpulkan bahwa tidak terjadi multikolonieritas dalam model ini.

Sedangkan pada hasil uji autokorelasi didapatkan hasil sebagai berikut:

Tabel 4. Hasil Uji Autokorelasi (Durbin-Watson)

Model Summary ${ }^{\text {b }}$

\begin{tabular}{|l|c|r|r|r|r|}
\hline Model & R & R Square & Adjusted R Square & Std. Error of the Estimate & \multicolumn{1}{c|}{ Durbin-Watson } \\
\hline 1 &, $426^{\mathrm{a}}$ &, 181 &, 131 &, 02343 & 1,348 \\
\hline
\end{tabular}

a. Predictors: (Constant), Lag_Leverage, Lag_Transaksi Hubungan Istimewa, Lag_Komisaris Independen,

Lag_Komite Audit

b. Dependent Variable: Lag_Effective Tax Rate

Pada tabel 4 menunjukkan DW dari output $=1,348$, nilai ini dibandingkan dengan nilai tabel signifikansi 5\%, jumlah sampel $\mathrm{N}=70$, dan jumlah variabel independen $(K=2)$ dan terdapat nilai DL adalah 1,5542 dan DU 1,6715 (dilihat dari tabel Durbin-Watson). Dapat dilihat bahwa DU 1,6715 > 1,348 (DU>DW) dan 4$1,6715(\mathrm{DU})=2,3285$ maka $1,6715(\mathrm{DU})>$ 1,348 (DW) $<2,3285$ (4-DU) sehingga data ini tidak lolos autokorelasi karena tidak sesuai dengan kriteria yaitu ( $\mathrm{DU}<\mathrm{DW}<4-\mathrm{DU})$.

Oleh karena itu hasil tersebut tidak lolos uji autokorelasi sehingga penulis akan menggunakan pengujian autokorelasi dengan menggunakan pengobatan chocrane orcutt seperti yang dikemukakan oleh Ghozali (2018:125). Berikut ini adalah tabel hasil dari pengujian cochrane orcutt:

Tabel 5. Hasil Uji Autokorelasi (Cochrane Orcutt)

Model Summary ${ }^{\text {b }}$

\begin{tabular}{|l|c|r|r|r|r|}
\hline Model & $\mathrm{R}$ & R Square & Adjusted R Square & Std. Error of the Estimate & \multicolumn{1}{c|}{ Durbin-Watson } \\
\hline 1 &, $377^{\mathrm{a}}$ &, 142 &, 089 &, 02224 & 1,801 \\
\hline
\end{tabular}

a. Predictors: (Constant), Lag_Leverage, Lag_Transaksi Hubungan Istimewa, Lag_Komisaris Independen, Lag_Komite Audit

b. Dependent Variable: Lag_Effective Tax Rate

Dapat dilihat bahwa DU $1,6715<1,801$ $(\mathrm{DU}<\mathrm{DW})$ dan $4-1,6715(\mathrm{DU})=2,3285$ maka 1,6715 (DU) < 1,801 (DW) $<2,3285(4-$ DU) sehingga dapat disimpulkan bahwa data tersebut lolos uji autokorelasi.

\section{Tabel 6. Hasil Uji Regresi Linier Berganda}

\begin{tabular}{|c|c|c|c|c|c|c|}
\hline \multicolumn{7}{|c|}{ Coefficients $^{\mathbf{a}}$} \\
\hline \multirow[b]{2}{*}{ Model } & & \multicolumn{2}{|c|}{$\begin{array}{l}\text { Unstandardized } \\
\text { Coefficients } \\
\end{array}$} & $\begin{array}{l}\text { Standardized } \\
\text { Coefficients } \\
\end{array}$ & \multirow[b]{2}{*}{$\mathrm{t}$} & \multirow[b]{2}{*}{ Sig. } \\
\hline & & $\mathrm{B}$ & Std. Error & Beta & & \\
\hline 1 & (Constant) & ,206 &, 030 & & 6,968 &, 000 \\
\hline & Komisaris Independen &,- 039 & ,015 &,- 299 & $-2,629$ & 011 \\
\hline & Komite Audit &, 016 & ,009 & ,209 & 1,765 &, 082 \\
\hline & $\begin{array}{l}\text { Transaksi Hubungan } \\
\text { Istimewa }\end{array}$ & ,007 & ,028 & 029 & ,244 &, 808 \\
\hline
\end{tabular}




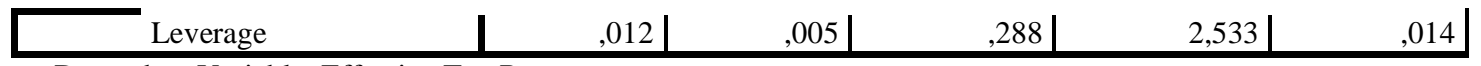

Berdasarkan hasil tabel 6 dapat dirumuskan persamaan regresi untuk linier berganda sebagai berikut:

$$
\begin{aligned}
& Y=\alpha+\beta_{1} X_{1}+\beta_{2} X_{2}+\beta_{3} X_{3}+\beta_{4} X_{4+} e
\end{aligned}
$$

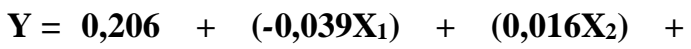

$$
\begin{aligned}
& \left(0,007 X_{3}\right)+\left(0,012 X_{4}\right)+e
\end{aligned}
$$

Keterangan :

$$
\begin{array}{ll}
\mathrm{Y} & =\text { Nilai Prediksi variabel dependen } \\
\alpha & =\text { Konstanta } \\
\mathrm{X}_{1} & =\text { Komisaris Independen } \\
\mathrm{X}_{2} & =\text { Komite Audit } \\
\mathrm{X}_{3} & =\text { Transaksi Hubungan Istimewa } \\
\mathrm{X}_{4} & =\text { Leverage } \\
\mathrm{e} & =\text { Variabel diluar model (error) }
\end{array}
$$

Berdasarkan persamaan regresi diatas dapat disimpulkan sebagai berikut :

1. Konstanta sebesar 0,206 artinya jika Komisaris Independen (X1), Komite Audit (X2), Transaksi Hubungan Istimewa (X3) dan Leverage (X4) sebagai variabel kontrol dianggap konstan, maka Effective Tax Rate
(Y) nilainya akan mengalami kenaikan sebesar 0,206.

2. Nilai koefisien regresi komisaris independen (b) bernilai negatif -0,039 ini dapat diartikan bahwa setiap peningkatan komisaris independen sebesar $1 \%$ maka effective tax rate akan menurun sebesar 0,039 .

3. Nilai koefisien regresi komite audit (b) bernilai positif 0,016 ini dapat diartikan bahwa setiap peningkatan komite audit sebesar $1 \%$ maka effective tax rate akan meningkat sebesar 0,016.

4. Nilai koefisien regresi transaksi hubungan istimewa (b) bernilai positif yaitu 0,007 ini dapat diartikan bahwa setiap peningkatan transaksi hubungan istimewa sebesar $1 \%$ maka effective tax rate akan meningkat sebesar 0,007.

5. Nilai koefisien regresi leverage sebagai variabel kontrol (b) bernilai positif yaitu 0,012 ini dapat diartikan bahwa setiap

\begin{tabular}{|c|c|c|c|c|c|c|}
\hline \multirow{2}{*}{\multicolumn{2}{|c|}{ Model }} & \multicolumn{2}{|c|}{$\begin{array}{l}\text { Unstandardized } \\
\text { Coefficients }\end{array}$} & \multirow{2}{*}{$\begin{array}{l}\text { Standardized } \\
\text { Coefficients } \\
\text { Beta }\end{array}$} & \multirow[b]{2}{*}{$\mathrm{t}$} & \multirow[b]{2}{*}{ Sig. } \\
\hline & & $\mathrm{B}$ & Std. Error & & & \\
\hline \multirow[t]{5}{*}{1} & (Constant) & ,206 &, 030 & & 6,968 & , 000 \\
\hline & Komisaris Independen &,- 039 &, 015 &,- 299 & $-2,629$ & 011 \\
\hline & Komite Audit & ,016 & 009 & ,209 & 1,765 & 082 \\
\hline & $\begin{array}{l}\text { Transaksi Hubungan } \\
\text { Istimewa }\end{array}$ & 007 & 028 & ,029 & ,244 & ,808 \\
\hline & Leverage &, 012 & 005 & ,288 & 2,533 & 014 \\
\hline
\end{tabular}
peningkatan leverage sebesar $1 \%$ maka effective tax rate akan meningkat sebesar 0,012 .

Sedangkan pengujian hipotesis untuk uji parsial (uji t) yang dilakukan sebagai berikut:

Tabel 7. Hasil Uji Parsial (Uji-t)

Coefficients $^{\text {a }}$

a. Dependent Variable: Effective Tax Rate

Berdasarkan output tabel 7 ditemukan bahwa nilai $t_{\text {tabel }}$ adalah 1,66757 dimana nilai tersebut berdasarkan (n-k) atau (70-2) $=68$ dengan menggunakan signifikansi 0,05 atau $5 \%$.

Berdasarkan tabel tersebut dapat disimpulkan mengenai uji hipotesis dari masing-masing variabel independen terhadap variabel dependen sebagai berikut:

1. Variabel komisaris independen memiliki nilai thitung $-2,629$ dan nilai ttabel sebesar 1,66757 maka $-2,629<1,66757$. Serta nilai signifikan yang diperoleh variabel komisaris independen sebesar 0,011 dan nilai signifikansi 0,05 maka $0,011<0,05$. Sehingga hal ini menandakan HO ditolak, maka variabel komisaris independen berpengaruh terhadap effective tax rate.

2. Variabel komite audit memiliki nilai thitung sebesar 1,765 dan nilai ttabel sebesar 1,66757 maka 1,765 > 1,66757. Serta nilai signifikan yang diperoleh variabel komite audit sebesar 0,082 dan nilai signifikansi 0,05 maka $0,082>0,05$. Sehingga hal ini menandakan $\mathrm{H} 0$ diterima, maka variabel komite audit tidak berpengaruh terhadap effective tax rate. 
3. Variabel transaksi hubungan istimewa memiliki nilai thitung sebesar 0,244 dan nilai ttabel sebesar 1,66757 maka $0,244<$ 1,66757. Serta nilai signifikan yang diperoleh variabel transaksi hubungan istimewa sebesar 0,808 dan nilai signifikansi 0,05 maka 0,808 $>0,05$. Sehingga hal ini menandakan H0 diterima, maka variabel transaksi hubungan istimewa tidak berpengaruh terhadap effective tax rate.

4. Variabel leverage sebagai variabel kontrol memiliki nilai thitung sebesar 2,533 dan nilai ttabel sebesar 1,66757 maka 2,533 > 1,66757. Serta nilai signifikan yang diperoleh variabel leverage sebesar 0,014 dan nilai signifikansi 0,05 maka $0,014<0,05$. maka variabel leverage berpengaruh terhadap effective tax rate.

Kemudian untuk pengujian hipotesis untuk uji simultan (uji F) yang dilakukan sebagai berikut:

\section{Tabel 8. Hasil Uji Simultan (Uji F)}

\begin{tabular}{|ll|r|r|r|r|r|}
\hline \multicolumn{1}{|c|}{ ANOVA $^{\mathbf{a}}$} & \multicolumn{1}{c|}{ Sig. } \\
\hline 1 & Sum of Squares & df & Mean Square & F &, $010^{\mathrm{b}}$ \\
& Regression &, 008 & 4 &, 002 & 3,603 & \\
& Residual &, 036 & 65 &, 001 & & \\
& Total &, 044 & 69 & & & \\
\hline
\end{tabular}

a. Dependent Variable: Effective Tax Rate

b. Predictors: (Constant), Leverage, Transaksi Hubungan Istimewa, Komisaris Independen, Komite Audit

Dari tabel 8 diperoleh $F_{\text {hitung }}$ sebesar 3,603 dan nilai signifikansi sebesar 0,010. $F_{\text {tabel }}$ dapat dilihat pada tabel statistik pada tingkat signifikansi 0,05 dengan df 1 (jumlah variabel 1) $=2$, dan df $2(\mathrm{n}-\mathrm{k}-1)$ atau 70-2-1 = 67 (n adalah jumlah data dan $\mathrm{k}$ adalah jumlah variabel independent), hasil diperoleh untuk $\mathrm{F}_{\text {tabel }}$ sebesar 3,13. $F_{\text {hitung }}>F_{\text {tabel }}(3,603>3,13)$ dan signifikansi $<0,05(0,010<0,05)$, maka H3 diterima, jadi dapat disimpulkan bahwa good corporate governance dan transaksi hubungan istimewa berpengaruh simultan terhadap Effective Tax Rate.

Pengujian hipotesis yang terakhir yaitu pengujian Koefisien Determinasi $\left(\mathrm{r}^{2}\right)$ didapatkan hasil sebagai berikut:

Tabel 9. Hasil Uji Koefisien Determinasi (Uji $\mathbf{r}^{\mathbf{2}}$ )

Model Summary ${ }^{b}$

\begin{tabular}{|l|r|r|r|r|}
\hline Model & \multicolumn{1}{|c|}{ R } & R Square & Adjusted R Square & \multicolumn{1}{|c|}{ Std. Error of the Estimate } \\
\hline 1 &, $426^{\mathrm{a}}$ &, 181 &, 131 &, 02343 \\
\hline
\end{tabular}

a. Predictors: (Constant), Leverage, Transaksi Hubungan Istimewa, Komisaris Independen, Komite Audit

b. Dependent Variable: Effective Tax Rate

Pada tabel 9 memperlihatkan Adjusted R Square adalah sebesar 0,131. Hal ini berarti sebesar $13,1 \%$ variabel effective tax rate dapat dijelaskan oleh variabel komisaris independen, komite audit, transaksi hubungan istimewa dan leverage sebagai variabel kontrol. Sedangkan sisanya sebesar $(100 \%-13,1 \%=86,9 \%)$ dijelaskan oleh variabel lain.

Pembahasan hasil analisis dari hipotesis bertujuan memberikan gambaran menyeluruh berkaitan dengan hasil pengujian tentang variabel yang diteliti yaitu pengaruh good corporate governance dan transaksi hubungan istimewa terhadap effective tax rate. Dalam bagian ini akan diterangkan pengaruh masingmasing variabel independen terhadap variabel dependen.

Berdasarkan hasil uji statistik t, bahwa variabel good corporate governance dengan proksi komisaris independen memiliki nilai $t_{\text {hitung }}$ sebesar $-2,629$ dan nilai $t_{\text {tabel }}$ sebesar 1,66757 serta nilai signifikan sebesar $0,011<$ signifikansi 0,05 . Hal ini dapat disimpulkan bahwa komisaris independen berpengaruh terhadap effective tax rate. Komisaris independen yang baik dalam perusahaan akan semakin meningkatkan kinerja perusahaan sehingga membuat manajer berhati-hati dalam menentukan tarif pajak efektif.

Hasil penelitian ini sejalan dengan penelitian yang dilakukan oleh Rahati Wulansari (2014), semakin banyak jumlah komisaris independen maka pengawasan terhadap agen akan semakin ketat. Banyaknya proporsi komisaris independen yang semakin besar dapat berpengaruh pada beban pembayaran pajak yang tinggi. Komisaris independen akan melaporkan jumlah pajak sesuai dengan tarif pajak yang berlaku terhadap keuntungan yang diperoleh perusahaan. 
Hasil penelitian ini tidak sejalan dengan penelitian yang dilakukan oleh Hashemi Rodhian Hanum dan Zulaikha (2013) yang menyatakan hal tersebut bahwa komisaris independen yang merupakan bagian dari dewan komisaris perusahaan yang tidak melakukan fungsi pengawasan dengan baik terhadap manajemen perusahaan. Proporsi yang lebih banyak dalam dewan komisaris independen tidak dapat memberikan jaminan bahwa perusahaan pemerintah akan berjalan dengan efektif dan baik sesuai dengan keinginan manajemen perusahaan. Komisaris independen dalam perusahaan pemerintah diindikasikan berperan sebagai pihak ketiga dimana posisnya netral antara pemerintah dan manajemen serta berperan aktif dalam penentuan kebijakan manajemen yang bersifat independen sehungga para investor akan lebih percaya kepada manajemen perusahaan.

Proksi selanjutnya dari good corporate governance adalah komite audit yang memiliki $\mathrm{t}_{\text {hitung }}$ sebesar 1,765 dan nilai $\mathrm{t}_{\text {tabel }}$ sebesar 1,66757 serta nilai signifikan sebesar 0,082 > signisikan 0,05. Hal ini dapat disimpulkan bahwa komite audit tidak berpengaruh terhadap effective tax rate.

Hasil penelitian ini sejalan dengan penelitian yang dilakukan oleh Hashemi Rodhian Hanum dan Zulaikha (2013) bahwa komite audit tidak berpengaruh terhadap effective tax rate karena hasil tersebut menunjukkan bahwa komite audit yang merupakan bagian dari perusahaan mempunyai tugas untuk melakukan pengawasan dan pengevaluasian terhadap kinerja operasional perusahaan tidak berjalan dengan baik. Keberadaan komite audit yang berfungsi untuk meningkatkan integritas dan kredibilitas pelaporan keuangan tidak berjalan dengan baik apabila tidak ada dukungan dari seluruh elemen dari dalam perusahaan. Berdasarkan hasil tersebut komite audit diindikasikan dalam pelaksanaannya kurang didukung oleh elemenelemen lain yang berada didalam perusahaan menjadikan komite audit gagal melakukan pengawasan yang baik dan cenderung bersifat netral. Berdasarkan hasil statistik menunjukkan bahwa komite audit merupakan karakteristik good corporate governance yang tidak berpengaruh terhadap effective tax rate (Sriwedari, 2009) dalam (Hashemi Rodhian Hanum dan Zulaikha, 2013).

Hasil penelitian ini tidak sejalan dengan penelitian yang dilakukan oleh Rahati Wulansari (2014) yang menyatakan bahwa variabel komite audit memiliki pengaruh dan signifikan karena hasil ini menunjukkan komite audit dapat berpengaruh pada penetapan kebijakan perusahaan dalam hal menentukan tarif pajak efektif perusahaan. Komite audit berfungsi memberikan pandangan mengenai masalah-masalah yang berhubungan dengan kebijakan keuangan, akuntansi, pengendalian internal perusahaan.

Berdasarkan hasil uji statistik t, bahwa variabel transaksi hubungan istimewa memiliki nilai $t_{\text {hitung }}$ sebesar 0,244 dan nilai $t_{\text {tabel }}$ sebesar 1,66757 Serta nilai signifikan yang diperoleh variabel transaksi hubungan istimewa sebesar $0,808>$ signifikansi 0,05 . Hal ini dapat disimpulkan bahwa transaksi hubungan istimewa tidak berpengaruh terhadap effective tax rate.

Hasil penelitian ini sejalan dengan penelitian yang dilakukan oleh Oktavia (2012) menyatakan bahwa transaksi hubungan istimewa tidak berpengaruh terhadap effective tax rate. Dimana semakin besar nilai transaksi hubungan istimewa, maka tarif pajak efektif perusahaan semakin menurun. Namun Hasil penelitian ini tidak sejalan dengan penelitian yang dilakukan oleh Kartika Pertiwi, Tumpal Manik, Asmaul Husna (2017) yang menyatakan bahwa transaksi perusahaan afiliasi berpengaruh terhadap tarif pajak efektif, Semakin tinggi transaksi afiliasi maka tarif pajak efektif akan semakin kecil. Dengan kata lain, keberadaan transaksi hubungan istimewa diperusahaan menyebabkan beban pajak yang dibayar oleh perusahaan. Temuan ini memperkuat dugaan bahwa transaksi hubungan istimewa yang dilakukan perusahaan, berdampak negatif terhadap penerimaan negara dari sektor pajak.

Hasil uji statistik F pada tabel 4.11 dapat diketahui bahwa nilai $\mathrm{F}_{\text {hitung }}>$ adalah 3,603 sedangkan nilai $F_{\text {tabel }}$ adalah sebesar 3,13. Karena $F_{\text {hitung }}>F_{\text {tabel }}$ dengan sig. $0,010<0,05$ maka H3 diterima, sehingga dapat disimpulkan bahwa variabel komisaris independen, komite audit dan transaksi hubungan istimewa berpengaruh terhadap effective tax rate.

Good corporate governance adalah suatu tata kelola yang menerapkan prinsip-prinsip keterbukaan (transparency), akuntabilitas (accountability), pertanggungjawaban (responsibility), profesional (professional), dan kewajaran (fairness). Tata kelola yang baik menuntut dibangun dan dijalankannya prinsip tersebut dalam proses manajerial. Melalui penerapan prinsip-prinsip universal diharapkan dapat menjamin keberlanjutan dan pencapaian kinerja perusahaan, sehingga perusahaan dapat memberikan manfaat kepada seluruh stakeholder (Hamdani, 2016). 
Pencapaian laba perusahaan tidak luput dari pemilihan keputusan yang tepat dalam melakukan kegiatan perusahaan. Keputusan yang diambil perusahaan harus efektif, efisien dan tepat termasuk dalam penentuan kebijakan yang terkait tarif pajak efektif. Besaran tarif pajak efektif perusahaan bergantung pada beberapa aspek perusahaan seperti dalam pemilihan metode akuntansi maupun adanya pengaruh langsung dari pemegang saham. Ketika suatu perusahan telah menerapkan good corporate governance yang baik maka akan tercipta kinerja perusahaanyang efektif dan akan berdampak pada keputusan yang efektif dalam menentukan kebijakan yang terkait besaran tarif pajak efektif perusahaan.

Globalisasi yang berkembang menyebabkan kegiatan ekonomi semakin berkembang hingga timbul adanya transaksi hubungan istimewa antar perusahaan. Transaksi yang terjadi antar pihak hubungan istimewa harus menerapkan prinsip kewajaran dan kelaziman. Perusahaan yang melakukan transaksi dengan pihak yang memiliki hubungan istimewa mendorong munculnya transfer pricing yang nantinya transfer pricing ini dapat digunakan oleh wajib pajak untuk meminimalkan jumlah pajak. Oleh karena itu, pajak yang dihasilkan perusahaan semakin kecil. Semakin majunya perkembangan perusahaan, maka perusahan dapat melakukan praktik transfer pricing kepada pihak-pihak yang memiliki hubungan istimewa dengan perusahaan tersebut untuk kebutuhan manajemen pajak. Namun, dalam melakukan praktik transfer pricing ini harus memperhatikan aturan yang berlaku sesuai dengan peraturan akuntansi dan aturan perpajakan.

\section{KESIMPULAN DAN SARAN}

Berdasarkan pembahasan dan hasil penelitian dapat diambil kesimpulan sebagai berikut:

1. Secara parsial, good corporate governance dengan proksi komisaris independen berpengaruh terhadap effective tax rate. Hal ini sejalan dengan penelitian yang dilakukan oleh Rahati Wulansari (2014).

2. Secara parsial, good corporate goveranance dengan proksi komite audit tidak berpengaruh terhadap effective tax rate. Hal ini sejalan dengan penelitian yang dilakukan oleh Hashemi Rodhian Hanum dan Zulaikha (2013).

3. Secara parsial, transaksi hubungan istimewa tidak berpengaruh terhadap effective tax rate.
Hal ini sejalan dengan penelitian yang dilakukan oleh Oktavia (2012).

4. Secara simultan, pengaruh good corporate governance dan transaksi hubungan istimewa terhadap effective tax rate menunjukkan hasil bahwa good corporate governance berpengaruh terhadap effective tax rate.

Sedangkan pembatasan dalam penelitian ini telah dilaksanakan sesuai dengan prosedur ilmiah, namun demikian penelitian ini masih memiliki beberapa pembatasan, yaitu:

1. Penelitian membatasi tahun observasi yaitu selama 5 tahun yang dimulai dari tahun 2013-2017 dengan tahun dasar 2013. Sampel ini hanya sebagian kecil dari sekian banyak perusahaan yang terdaftar di BEI, sehingga dapat dikatakan hasil penelitian ini kurang memberikan gambaran secara keseluruhan dari populasi perusahaan yang terdaftar di BEI selama tahun penelitian.

2. Faktor-faktor yang mempengaruhi effective tax rate dalam penelitian ini hanya terdiri dari 2 variabel, yaitu good corporate governance dan transaksi hubungan istimewa, sedangkan masih banyak faktor lain yang mempengaruhi effective tax rate.

Kemudian berdasarkan interprestasi hasil dan kesimpulan yang diperoleh, maka saran yang disampaikan untuk dapat dijadikan acuan bagi penelitian yang akan datang adalah:

1. Bagi para praktisi agar lebih memperhatikan kondisi good corporate governance dan transaksi hubungan istimewa sehingga dapat memaksimalkan efisiensi pajak melalui penetapan tarif pajak efektif. Selain itu para praktisi juga dapat melihat literatur lain yang membahas mengenai tarif pajak efektif sebagai acuan.

2. Bagi penelitian berikutnya, diharapkan dapat menambah variabel lain yang dapat mempengaruhi effective tax rate sehingga diharapkan dapat diperoleh hasil yang lebih signifikan.

\section{DAFTAR PUSTAKA}

Annisa, Nuralifmida Ayu. 2011. Pengaruh Corporate Governance Terhadap Tax Avoidance. Universitas Sebelas Maret.

Ardyansah, Danis. 2014. Pengaruh Size, Leverage, Profitability, Capital Intensity Ratio dan Komisaris Independen Terhadap Effective Tax Rate (ETR). Universitas Diponegoro: Semarang.

Ariani, Miza. 2018. Pengaruh Profitabilitas, Likuiditas, Leverage, Size, dan Capital 
Intensity Ratio Terhadap Effective Tax Rate (ETR). Perbanas Institute Jakarta. Profita: komunikasi Ilmiah Akuntansi dan Perpajakan. Vol. 1, No.3 | Desember 2018. p-ISSN: 2086-7662. e-ISSN: 2622-1950.

Bachtiar, Muhammad Danu. 2015. Pengaruh Struktur Kepemilikan, Ukuran Perusahaan, dan Capital Intensity Rasio Terhadap Effective Tax Rate. Universitas Diponegoro: Semarang.

Badan Pengawas Pasar Modal dan Lembaga Keuangan, 2004. Kep-29/PM/2004. "Pembentukan dan Pedoman Kerja Komite Audit".

Badan Pengawas Pasar Modal, 2012. Kep643/BL/2012. "Pembentukan dan Pedoman Pelaksanaan Kerja Komite Audit".

Diantari, Rista Putu dan Ulupui, Agung IGK. 2016. Pengaruh Komite Audit, Proporsi Komisaris Independen dan Proporsi Kepemilikan Institusional Terhadap Tax Avoidance. E-Jurnal Akuntansi Universitas Udayana. Vol. 16.1. Juli (2016): 702-732. ISSN: 2302:8556.

Ghazali, Imam. 2018. Aplikasi Analisis Multivariate Dengan Program IBM SPSS 25 Edisi 9.

Hamdani. 2016. Good Corporate Governance Tinjuan Etika dalam Praktik Bisnis. Jakarta : Penerbit Mitra Wacana Media.

Handayani, Desi dan Arfan, Tobi. 2014. Pengaruh Transaksi Perusahaan Afiliasi Terhadap Tarif Pajak Efektif. Politeknik Caltex Riau. Jurnal Akuntansi Keuangan dan Bisnis. Vol.7, Bulan 2014, 11-19.

Hanum, Rodhian Hashemi dan Zulaikha. 2013. Pengaruh Karakteristik Corporate Governance Terhadap Effective Tax Rate. Diponegoro Journal Of Accounting.http://ejournals1.undip.ac.id/index.php/accounting. Vol 2. No. 2. Tahun 2013. Halaman 1-10. ISSN (Online): 2337-3806.

Ikatan Akuntansi Indonesia. 2010. Pernyataan Srandar Akuntansi Keuangan (PSAK) No. 7 (Revisi 2010). Jakarta.

Karayan, John E and Charles W.Swenson. 2007. Strategic Business Tax Planning, 2nd Edition. New Jersey: John Wiley \& Sons Inc.

Komite Nasional Kebijakan Governance (KNKG), 2006. Pedoman Umum Good Corporate Governance Indonesia. www.governace-indonesia.com.

Kurniasih, Tommy dan Sari, Maria M Ratna. 2013. Pengaruh Return On Assets, Leverage, Corporate Governance, Ukuran
Perusahaan, Kompensasi Rugi Fiskal Terhadap Tax Avoidance. Universitas Udayana. ISSN 1410-4628.

Malinda, kori Putri. 2017. Pengaruh Karakter Eksekutif dan Good Corporate Governance Terhadap Tax Avoidance. Universitas Pamulang.

Meilinda, Maria. 2013. Pengaruh Corporate Governance Terhadap Manajemen Pajak. Diponegoro Journal Of Accounting. http://ejournals1.undip.ac.id/index.php/accounting. Volume 2, Nomer 3, Tahun 2013, Halaman 1. ISSN (Online): 2337- 3806.

Oktavia. 2012. Transaksi Hubungan Istimewa dan Pengaruhnya Terhadap Tarif Pajak Efektif Perusahaan. Universitas Kristen Krida Wacana.

Rifkhan. 2018. Faktor-Faktor Yang Mempengaruhi Kinerja Dosen Universitas Pamulang. Jurnal Renaissance, Agustus, Volume 3, No 2, Halaman 358-373. Jakarta : Prima Center Indonesia.

Sugiyono. 2016. Metode Kuantitatif, Kualitatif, dan R \& D. Cetakan ke-23, April 2016.

Pertiwi, Kartika. Manik, Tumpal dan Husna, Asmaul. 2017. Pengaruh Intensitas Moda, Leverage, Intensitas Persediaan, Transaksi Perusahaan Afiliasi dan Transfer Pricing Terhadap Tarif Pajak Efektif pada Perusahaan Manufaktur yang Terdaftar di Bursa Efek Indonesia Tahun 2013-2016.

Prastitih, Anindyah dan Meiranto, Wahyu. 2013. Pengaruh Karakteristik Dewan Komisaris dan Komite Audit Terhadap Manajemen Laba. Diponegoro Journal Of Accounting.http://ejournal-

s1.undip.ac.id/index.php/accounting.volum e 2. No. 4. Tahun 2013. Halaman 1-12. ISSN (Online): 2337-3806.

Rachmithasari, Annisa Fadilla. 2015. Pengaruh Return On Asset, Leverage, Corporate Governance, Ukuran Perusahaan dan Kompensasi Rugi Fiskal Pada Tax Avoidance (Perusahaan Manufaktur yang Terdaftar di Bursa Efek Indonesia). Skripsi Jurusan Akuntansi Fakultas Ekonimo dan Bisnis Universitas Muhammadiyah Surakarta, Surakarta.

Republik Indonesia. 2008. Undang-undang No. 36 Tahun 2008 Tentang Pajak Penghasilan. Lembaga Negara RI Tahun 2008. Sekretariat Negara. Jakarta.

Republik Indonesia. 2013. Peraturan Pemerintah No. 46 Tahun 2013 Tentang Penyederhanaan Perhitungan Pajak. Lembaga Negara RI Tahun 2013. Sekretariat Negara. Jakarta. 
Setiawan, Ade dan Al ahsan, Khaliq Muhammad. 2016. Pengaruh Size, Leverage, Profitability, Komite Audit, Komisaris Independen dan Investor Konstitusional Terhadap Effective Tax Rate (ETR). Fakultas Ekonomi dan Bisnis Islam IAIN. Surakarta. Indonesia.

Suyanto, Krisnata Dewi dan Supramono. 2012.

Likuiditas, Leverage, Komisaris Independen dan Manajemen Laba Terhadap Agresivitas Pajak Perusahaan. Universitas Kristen Satya Wacana Ponegoro. Jurnal Keuangan dan Perbankan. Vol 16, No. 2 Mei 2012, hlm. 167-177.

Wulansari, Rahati. 2014. Pengaruh Karakteristik Corporate Governance Terhadap Effective Tax Rate (ETR). Faculty of Economic Riau University. Pekanbaru. Indonesia.

www.pemeriksapajak.blogspot.com/2014/11/atu ran-hubungan-istimewa-dalam.html, diakses tgl 23 April 2019

www.idx.co.id.

www.jdih.bumn.go.id/lihat/KEP-117/M-

MBU/2002

www.nasional.kontan.co.id 